\title{
Using Procedural and Conceptual Colour Stimulation-Game as An Instructional Gizmo for Nigerian Students
}

\author{
ODEWUMI Michael Olubunmi \\ Department of Educational Technology \\ Faculty of Education. \\ University of Ilorin. Ilorin. \\ Nigeria. \\ agbegilerebunmi2@gmail.com
}

\author{
Ola-Alani, Eniola Keji \\ Department of Adult Education, \\ Faculty of Education. \\ University of Ilorin. Ilorin. \\ Nigeria. \\ childhoodeducationmyconcern@gmail.com
}

\begin{abstract}
This research study focused on investigating on the effect of colour stimulation-game on Nigerian Junior secondary school creative arts by adopting quasi-experimental research design with 60 junior secondary schools of three coeducational, from Private, Public and Federal Secondary Schools using simple random sampling technique to randomly select The three secondary schools assigned to both experimental and control groups. With the aid of two instruments which were The Colour Stimulation-game and Colour Stimulation-Game Achievement Test (CSGAT), the data was collected. Frequency counts and percentage distribution, mean, standard deviation, independent $t$ test, ANOVA and ANCOVA were used to analyse the data demographic information, the research question and the hypothesis generated respectively. The researcher found out that the students taught with Stimulus perform better after treatment than the student taught with conventional teaching method, students taught with Colour Stimulus game performed better when exposed to treatment than their students taught with conventional teaching method and female students taught with Colour Stimulus game performed better than their male students. It was recommended that that creative arts instructors should utilizes, colour stimuli game and reducing conventional method do as to impact the appropriates knowledge for students
\end{abstract}

Keywords-- Colour Stimulation-Game, Colour, Game and instruction, Game, Significant in games.

\section{INTRODUCTION}

Technology has brought advancement to teaching methods by encouraging graduation from simple to complex concept. Different methods and tools are of importance for facilitating and fulfilling objectives [1]. The study of [2] observed that active learning ideas create unconventional, creative and fun for teaching and learning environments to fulfil the stated objectives. The aforementioned attributes are prominent in game evident as instructional medium. Games is an interactive activity which involves participants contesting for a goal based on an accepted rule. Many studies have expressed the meaning of game in diverse ways. For example, [3] defined game as a contest in which different people come together to agree on certain rules and principles in other to win a specific goal. In another words, it is a social activity within the context of agreement with prescribe rules towards a stated goal [4]. The study of [5] delineated game as a system in which the contestants are the active players and engage in artificial rigour such as conflict, on the basis of stipulated rules, that result in one encouraging as over comer or winner.

The study of [6] explained that games are in numerical and alphabetical structure which are meant for developing cognitive gradual learning process in individual. In the same vein, [7] further submitted that game is also a learning device in diverse form. Games is an effective and motivational instruction medium [8]. Games serves as a formative form of evaluation and method of appraisal [9]. A unique tool in instruction that enhances and widens students' knowledge academically [10]. In another study of [11] specified that educational game is a unique game which is designed to teach individual about a specific thing, an interactive and a problem solving. Although student expending time on game can cause backwardness in education but educative games are imperative in teaching and learning.

Many studies have been done on game and instruction. For example, the study of [12] uncovered games as a tool for teaching and learning process which has recorded a great significant result. Also, [13] studied the influence of gamebased learning strategies on instruction, the study concluded with the positive attitudes of learners toward the game. In the same view, [14] researched on the effect of simulation-games and environment on learner's achievement in mathematics, the findings show that using simulation games environment brings about noticeable and positive attitude to teaching and learning of mathematics.

In another development [15] investigated the effect of simulation games and brainstorming strategies on teaching of social studies students. The results divulged that there was a strong significant and positive development of the treatment and gender on the student's performances in the discipline. [16] and [17] stressed the use of game in instructions, it enhances learning and promotes understanding of abstract concept. [18] conducted a research on the effect of teaching and learning of mathematics with game, the findings showed that bi-model was 
significantly effective in facilitating students' achievement in mathematics than modified lecture method. In essence, [19] study suggested that complementing and manipulating visual materials along with verbal promotes discovery in learning in gaming context.

Furthermore, studies have argued the usefulness of game in term of educational context. For example, [20] mentioned that types of games involving role learning brings success, improves memorization and stimulates individual student's health. [21] observed that Video games as being useful in teaching K-12 classrooms across the globe because it widens the pupils experience and enhances learning. Likewise [22] submitted that gaming provides constant opportunities of practicing to eludes failure, because failure is inevitable in acquiring learning experience. In essence, [23] gaming has unique opportunities to achieve formative process of instruction. [24] mentioned that pupils are more active when there is a space for narrating story within the games. Fleer [25] concluded that pretend play creates in pupils' foundations for self-actualisation and reflection. He further stressed that it develops some innate skills in pupils. [26] and [27] stressed that games motivate, develop skills, abilities and strategies in different discipline including Geography

Many studies have been done on gender and game. For example, [28] investigated games and simulations outcome on the gender differences on mathematics. The results revealed that there was a significant interaction on the effect of treatment and gender of students' achievement. [29] carried out a study on the problem-solving performance of male and female students in mathematics, the study concluded that boys and girls performed equally and no significant difference. [30] also researched on gender inequality among the mathematics students in rural male and female students of Cross River State. $\mathrm{He}$ concluded that there are existence of clear significance on gender achievement gap which favour only the rural male students. [31] submitted that girls are mostly engaged in game for discoveries in learning than male counterparts.

Although colour is important in development and learning of creative arts. Colour can be seen and identify by everybody, but the mode of identification and names given to each colour are different in their regards. A single colour can be converted to many colours through tint and shade, but these colours cannot be identified with original names because of influence of the name ascribe to each colour by lay people. Colour in junior secondary schools' curriculum has been treated with different teaching strategies.

Moreover, studies have been conducted on game in education globally. For instance, [32] examined game as an active and interesting tool for students learning of Mathematics. [33] conducted a study on the game and its effectiveness in teaching Social studies. [34] reported that simulation games increase students' participation and interest in Integrated Science. In essence, [35] stated that game-based strategy has the ability to produce game flow in learners which can motivate and increase the interest of students towards improve their studies. The students and the teachers have not exposed adequate to the merit of game strategies in teaching and learning. The study therefore intends to fill the gap created by the previous study on the colour stimulation-game as a tool for teaching colour in Junior secondary.

\section{RESEARCH QUESTIONS}

These research questions were produced to guide the study:

(1). is there any difference in the student's performances when taught with colour stimulation-game and those taught with the conventional method?

(2). does the gender of students have influence on the performances in creative arts when they are exposed to colour stimulation-game?

(3). what is the influence of school type on the student's performances exposed to colour stimulation-game?

\section{RESEARCH HYPOTHESES}

The following three hypotheses have been formulated to serves as guide for the research study in line with the aforementioned research questions:

Hypotheses 1 (H1): There is no significant difference in the performance of students taught using colour stimulation-game and those taught using the conventional method.

Hypotheses 2 (H2): There is no significant difference in the performance of male and female students taught using colour stimulation-game.

Hypotheses 3 (H3): There is no significant difference in the performance of students in the public, private and unitary owned school colour stimulation-game.

\section{RESEARCH DESIGN}

The study used quasi-experimental type of research design which involves the use of pre-test, post-test, and control group. It also used purposive sampling method to select two different schools based on the following; the school has the largest population of qualified creative and visual arts teacher. The school has been producing creative arts students in the Basic Examination Certificates (junior secondary school certificate) examination for the past ten years. There are enough studio, material and equipment of arts.

The sample comprised 60 junior secondary schools of three co-educational, from Private, Public and Federal Secondary Schools. The three secondary schools were randomly assigned to both experimental and control groups. The two instruments used for the study were: The Colour Stimulation-game and Colour Stimulation-Game Achievement Test (CSGAT).

The Colour Stimulation-game described as follows:

\section{A. Materials:}

A ventilated Visual and Creative Art Studio with a source of power supply. A big and functional light table. Tracing colour paper of 3 by 4 inches. Colour sample cardboard of 4 by 4 inches. Names and Colours exhibition cardboard. 


\section{B. Process of playing Colour game formation:}

A 4 by 4 coloured cardboard is placed before the participant asking them to search for the solution and name of the colour. The participant will be placing the 3 by 4 inches colour tracing papers one by one on each other till the actual colour is gotten. The participant will now search for the name of colour on the exhibition cardboard. The faster the player is able to get more scores; thus, the game is played by group and by individuals.

The 'researcher having provides the necessary information on the game, allowed the students to continue playing the game under close monitoring and supervision while experienced creative teacher was employed to teach the conventional group with appropriate instructional media on the following topics which the game were based: identification and mixtures of Primary, Secondary and Tertiary colours, Colour tint and shade, Colour vocabularies and theories all were based on the Junior secondary school two creative arts curriculum. On the Colours Stimulation-Game Achievement Test (CSGAT), the test consisted of 50 objective test past question from the National Examination Council (NECO) validated Junior Certificate Examination.

\section{Research Questions}

The research questions were answered as follows the post-test Mean of 32.93 is bigger than the pre-test Mean of 12.18. The result shows that the students taught with Stimulus perform better after treatment than the student taught with conventional teaching method as stated in the table 1.

TABLE 1: THE MEAN OF STUDENTS TAUGHT WITH COLOUR STIMULATION-GAME AND THOSE TAUGHT WITH THE CONVENTIONAL METHOD

\begin{tabular}{|c|c|c|c|c|c|c|}
\hline Variable & \multicolumn{3}{|c|}{ Pre-test } & \multicolumn{3}{c|}{ Pre-test } \\
\cline { 2 - 7 } & Mean & $\mathrm{N}$ & Std. & Mean & $\mathrm{N}$ & Std. \\
\hline Students. & 12.18 & 60 & 1.66 & 32.93 & 60 & 4.99 \\
\hline
\end{tabular}

TABLE 2: THE PRE-TEST AND POST TEST MEAN OF THE SCHOOLS EXPOSED TO COLOUR STIMULATION-GAME.

\begin{tabular}{|l|l|l|l|l|l|l|}
\hline Variable & \multicolumn{3}{|c|}{ Pre- test } & \multicolumn{3}{c|}{ Post-test } \\
\cline { 2 - 7 } & Mean & $\mathrm{N}$ & Sd. & Mean & $\mathrm{N}$ & Sd. \\
\hline State & 12.85 & 20 & 2.37 & 41.70 & 20 & 5.18 \\
Private & 11.95 & 20 & 1.67 & 35.30 & 20 & 3.03 \\
Federal & 12.35 & 20 & 1.60 & 38.00 & 20 & 3.96 \\
\hline
\end{tabular}

The post-test mean of state public 5.188 is bigger than the pre-test mean of 12.85 also the post-test Mean of private junior secondary school 3.027 is higher than the pre-test mean of 11.95 and the post-test mean of federal government college 3.96 is bigger than the pre-test mean of 12.35 therefore, the result revealed that students taught with Colour Stimulus game performed better when exposed to treatment than their students taught with conventional teaching method.

Moreover, the post-test mean of female of 35.37 is bigger than the post-test mean of male 30.50 this proved that the female students taught with Colour Stimulus game performed better than their male students reflects in Table 3 ,

\section{Testing Of Hypotheses}

$H 1$ : There is no significant difference in the performance of students taught using Colour Stimulation-game and those taught using the conventional method.

To test this hypothesis the post-test Mean scores of the Colour stimulation-game and convention was analysed with Analysis of Covariance (ANCOVA)using the pre-test as the covariance.

TABLE 3: THE MEAN OF MALE AND FEMALE STUDENTS EXPOSED TO COLOUR STIMULATION-GAME.

\begin{tabular}{|r|r|r|r|r|r|r|}
\hline Variable & \multicolumn{3}{|c|}{ Pre- test } & \multicolumn{3}{c|}{ Post-test } \\
\cline { 2 - 7 } & \multicolumn{1}{|c|}{ Mean } & \multicolumn{1}{|c|}{ N } & Std. D & Mean & N & Std. D \\
\hline Male & 12.27 & 30 & 1.60 & 30.50 & 30 & 5.23 \\
Female & 12.10 & 30 & 1.73 & 35.37 & 30 & 3.32 \\
& & & & & & \\
\hline
\end{tabular}

TABLE 4: ANALYSIS OF COVARIANCE (ANCOVA) ON THE POST-TEST PERFORMANCE SCORE OF COLOUR STIMULATION-GAME USING THE PRE-TEST AS COVARIATE.

\begin{tabular}{|l|r|r|r|r|r|}
\hline Source & $\begin{array}{c}\text { Type III } \\
\text { Sum of } \\
\text { Squares }\end{array}$ & \multicolumn{1}{|c|}{ Df } & \multicolumn{1}{c|}{$\begin{array}{c}\text { Mean } \\
\text { Square }\end{array}$} & \multicolumn{1}{|l|}{ F } & Sig. \\
\hline Corrected Model & $144.944 \mathrm{a}$ & 3 & 48.315 & 6.910 & .003 \\
Intercept & 2.020 & 1 & 2.020 & .289 & .598 \\
State Public Sch. & 29.390 & 1 & 29.390 & 4.203 & .056 \\
Private School & 5.772 & 1 & 5.772 & .826 & .376 \\
Federal G. C. & 12.240 & 1 & 12.240 & 1.751 & .203 \\
Error & 118.866 & 17 & 6.992 & & \\
Total & 3409.000 & 21 & & & \\
Corrected Total & 263.810 & 20 & & & \\
\hline
\end{tabular}

Table 4 shows the clear comparison of the post-test mean score of colour stimulation-game and control groups. The calculated $F$ value of 1.751 is greater than.05 alpha level. This result implies that there was no significant difference between the post-test mean scores of the colour stimulation-game and control group. That is the scores did not differ significantly between the colour stimulation-game and control groups with colour stimulation-game group performing better. Therefore, the null hypothesis is not rejected.

H2: There is no significant difference in the performance of male and female students taught using Colour stimulation-game.

To test these hypotheses t-test statics is used to compare the mean scores of both the female and male students showing in the table 5 .

Table 5 shows vividly the comparison of the post-test mean score of the male and female students in public, private and unitary junior secondary schools. The calculated $\mathrm{p}-\mathrm{F}$ value of 1.281 is greater than .205 alpha level. This result shows that there is no significant difference between the post-test mean scores of male and female. That is the male score did not differ significantly from female scores when both were taught with the Colour stimulation-game. Therefore, the null hypothesis is not rejected, in table 5 .

H3: There is no significant difference in the performance of students in the State Public, Private and Federal 
Government College School taught with colour stimulationgame.

To test this hypothesis the analysis of analysis of co variance (ANNOVA) is used to analysis the mean of the three schools, in table 6 .

TABLE 5: T-TEST OF THE MALE AND FEMALE POST TEST MEAN SCORES

\begin{tabular}{|c|c|c|c|c|c|c|}
\hline Variables & $\mathbf{N}$ & Mean & Std. D. & Df & t-value & $\begin{array}{c}\text { Sig.(2- } \\
\text { tailed ) }\end{array}$ \\
\hline Boys & 30 & 39.13 & 5.859 & 58 & 1.281 & .205 \\
\hline Girls & 30 & 37.53 & 3.530 & & & \\
\hline
\end{tabular}

TABLE 6 ANALYSIS OF COVARIANCE ON THE MEANS SCORE OF THE THREE SCHOOLS

\begin{tabular}{|l|r|r|r|r|r|}
\hline Source & \multicolumn{1}{|c|}{$\begin{array}{c}\text { Type III } \\
\text { Sum of } \\
\text { Squares }\end{array}$} & \multicolumn{1}{|c|}{ df } & \multicolumn{1}{c|}{$\begin{array}{c}\text { Mean } \\
\text { Square }\end{array}$} & \multicolumn{1}{|c|}{ F } & Sig. \\
\hline Corrected Model & $412.933 \mathrm{a}$ & 2 & 206.467 & 11.979 & .000 \\
Intercept & 88166.667 & 1 & 88166.667 & 5115.533 & .000 \\
Factor & 412.933 & 2 & 206.467 & 11.979 & .000 \\
Error & 982.400 & 57 & 17.235 & & \\
Total & 89562.000 & 60 & & & \\
Corrected Total & 1395.333 & 59 & & & \\
\hline
\end{tabular}

R Squared $=.296($ Adjusted R Squared $=.271)$

Table 6 clearly shows the calculated F value of 11.979 is a significant difference because .000 significance level is less than 0.05 alpha levels. This shows that there is a significant difference in the post-test mean score of the private, state and federal own junior secondary school. Therefore, the null hypothesis is rejected

\section{DISCUSSION}

The study used procedural and conceptual colour stimulation-game as an instructional gizmo for Nigerian students and the result was stated to be effectiveness and significantly for both male and female students.

The null hypothesis one (1) and three (3) were rejected this was based on reference to the findings. These agreed with the earlier finding of [36] who revealed that males' students significantly better than females when exposed to teaching of Mathematics through game. Also, the findings are in supports of [37] established that instructors reported that the using gamebased learning significantly increases learner's motivation and engagement activities in classroom. In the similar vein, it supported the findings of [38] who authenticated that gamesbased strategy are more effective in improving the pupils cognitive learning. Also, the finding is in favoured of [39] who stressed the effectiveness of the use of game in mathematics instruction with the result that students who are exposed to Game strategies achieved significantly better than the lecture strategies. This finding concurred with [40] who revealed that game-based learning promotes permanency in term of longterm learning. The study also supports the longitudinal cram conducted by [41] who stressed that game increasingly causing significant shifts in every facet of society in terms of different tradition. In essence, it is also agreed with the findings of [42] who presented game as a powerful tool that is of significance importance and improves instructions.

The null hypothesis based on gender in Table 5 is not rejected. Therefore, the result is in compliance with the findings of some other earlier researches which revealed a significant difference in the success of male and female students in mathematics in favour of male. This also, authenticates the findings of [43] who studies exposed to teaching strategies through Game. Similarly, it supports the findings of [44] who stressed that both male and female students exposed to the same rigorous and driven game-based teaching performed equally.

In other words, the finding disagrees with the [45] whose study opposes the findings of [46] on male students that were active than female when engaging in educative playing games playing. However, it contradicts the study of [47] which is based on his literature reviewed on game. More so, the findings were contrary to the early findings of [48] who found that there is no indicated and no significant difference between the achievement of male and female students in mathematics through their exposure to Game.

\section{CONCLUSION}

The study concluded that students taught with the colour stimulation-game instruction performed significantly better in comparing with those students taught with conventional method of instruction. In the same vein, male and female students performed significantly better in Creative arts Colour aspect when taught with Colour Stimulation-Game.

\section{RECOMMENDATION}

Based on the findings on the study, it was recommended that teacher and other instructors should utilizes technology into their various teaching methodology by teaching with stimulus, colour stimuli game and reducing conventional method do as to impact the appropriates knowledge for students. Furthermore, cognisance should be taken in term of lesson delivery among the male and female so as to balance their academic achievement in class. Aside that concerned stakeholders should embrace the utilization of technologies in the process of teaching in order to promotes the learning outcome of students in various school settings.

\section{REFERENCE}

[1] M. Z. Nasab, R. Esmaeili, \& H. N. Sarem, "The use of teaching aids and their positive impact on student learning elementary school". International Academic Journal of Social Sciences, vol.2, no. 11, pp.22-27, 2015.

[2] A. A. Weltman, "Comparison of traditional and active learning methods: a n empirical investigation utilizing a linear mixed model. Unpublished paper Presented to the Faculty of the Graduate School of The University of Texas at Arlington in Partial Fulfilment of the Requirements for the Degree of Doctor of Philosophy the University of Texas at Arlington, 2007.

[3] O. Aremu, "Adapting Ludo as a resource material for effective mathematics communication in primary school. STAN 44th Conference Proceedings pp. 261-263, 2003. 
[4] O. Ezeamaenyi \& B. C. Alio. "The Roles of Mathematics in Information Technology: Implication for the Society. ABACUS:" The Journal of The Mathematical Association of Nigeria (MAN), vol. 29, no.1, pp.7-8. 2004.

[5] K. Salen, \& E. Zimmerman, "Rules of play: game design fundamentals". Cambridge, MA: MIT Press, pp. 34. 2004.

[6] E. Klopfer, "Augmented learning: Research and design of mobile educational games" MIT Press. 2008, pp. 56-60.

[7] R. C. Thomas, \& C. D. Milligan, "Putting Teachers in the Loop: Tools for Creating and Customising Simulations". Journal of Interactive Media in Education (Special Issue) vol.15. pp. 54-60, 2004.

[8] M. Papastergiou. "Digital game-based learning in high school computer science education: impact on educational effectiveness and student motivation". Computers \& Education, vol. 52, pp. 1-12, 2009.

[9] G. C. Delacruz. "Games as formative assessment environments: Examining the impact of explanations of scoring and incentives on math learning, game performance, and help seeking" .(CRESST Report 796). Los Angeles, CA: University of California, National Center for Research on Evaluation, Standards, and Student Testing (CRESST). 2011.

[10] P. Wastiau, C. Kearney, W. Van den Berghe, (2009). "How are digital games used in schools"? European Schoolnet. Available: http://games.eun.org

[11] M. Prensky, "Fun, Play and Games: What Makes Games Engaging." Digital Game-Based Learning. McGraw-Hill, 2001, pp, 57-69.

[12] U. I. Prince, "Effect of mathematics game-based instructional techniques on students' achievements and interest in algebra", At Basic Education Level Department of Science Education, Faculty of Education University of Nigeria, Nsukka. 2014.

[13] L. Yueh-Chiao, "The influence of applying a game-based leaning approach to nutrition education". The Turkish Online Journal of Education Technology, vol. 10 no2, pp.1-10. 20

[14] S. Rigby, \& R. Ryan, (2007). "The player experience of need satisfaction (PENS) model”. Available: ftp://ftp.immersyve.com

[15] B. A. Adeyemi, \& Y. A. Ajibade, "The comparative effects of simulation games and brainstorming instructional strategies on junior secondary school students' achievement in social studies in Nigeria". An International Multi-Disciplinary Journal, Ethiopia, vol. 5, no, 3, pp. 64-80.2011

[16] Aremu, "Effects of card and geoboard game-based instructional strategies on primary school pupils' achievement in practical geometry". PhD. Thesis. Dept. of Teacher Education University of Ibadan, Ibadan. 1998.

[17] U. N. V. Agwagah, "Mathematical games for primary schools". Nsukka: Mike Social Press.2001.

[18] E. Okigbo, \& N. F. Okeke. "Game and analogy: A bi-model for effective instruction in the Nigerian mathematics classroom". Universal Journal of Education and General Studies Online Journal of Education Technology, vol. 3 no. 11, pp 34-45. 2013

[19] R. O. Ohuche, "Explore mathematics with your children. Onitsha: Summer Educational Publishers Ltd., pp. 70 -79. 1990

[20] S. Egenfeldt-Nielson, "Third generation educational use of computer games". Journal of Educational Multimedia and Hypermedia, vol. 16 no.3, pp. 263-281. 2007.

[21] P. Wastiau, C. Kearney, W. Van den Berghe, (2009). "How are digital games used in schools"? European Schoolnet.Available: http://games.eun.org

[22] J. Groff, C. Howells, \&S. Cranmer, "The impact of console games in the classroom: Evidence from schools in Scotland". UK, 2010, pp, 2130

[23] M. Heritage, "Formative assessment and next-generation assessment systems: Are we losing an opportunity? Washington, DC: 2010, pp, 30-36.

[24] S. A. Barab, A. Arici, \& C. Jackson, "Eat your vegetables and do your homework: A design based investigation of enjoyment and meaning in learning". Educational Technology, vol. 45, no.1, pp. 15-20. 2005.

[25] M. Fleer, "Early learning and development: Cultural-historical concepts in play. Melbourne, Australia: Cambridge University Press. 2010, pp. 16-20.
[26] F. B. Eze, Effect of mathematical scrabble games on achievement and interest in computational skills in junior secondary school. M.ED Thesis University of Nigeria Nsukka. 2006.

[27] H. Tüzün, M. Yilmaz-Soylu, T. Karakus, Y. Inal, \& G. Kizilkaya,. The effects of computer games on primary school students' achievement and motivation in geography learning. Computers and Education, vol. 52, no. 1, pp. 68-77, 2009

[28] E. E. Achor, B. I.Imoko, "Sex differentials in students' achievement and interest in geometry using games and simulations technique". Necatibey Faculty of Education Electronic". Journal of Science and Mathematics Education, vol. 4 no, 1, pp.1-10, 2010.

[29] M. A. Adeleke, "Strategic improvement of mathematical problemsolving performance of secondary school students using procedural and conceptual learning strategies. The African Symposium": An online Journal of African Educational Research Network, vol. 8, no. 1, pp.143-149. 2008.

[30] S. W. Bassey, M. T. Joshua and A. E. Asim, "Gender differences and mathematics achievement of rural senior secondary students in Cross River State, Nigeria. Proceedings of International Conference to Review Research in Science, Technology and Mathematics. 2008.

[31] M. Kinzie, \&D. Joseph, "Gender differences in game activity preferences of middle school children: Implications for educational game design". Educational Technology Research and Development, vol. 56 no.5/6, pp. 643-663. 2008.

[32] B. Abubakar, \& M. Bawa, "Effect of the use of number base game on senior secondary school students' achievement in number bases. ABACUS". Journal of Mathematical Association of Nigeria, vol. 31, no. 1, pp. 103-114. 2006.

[33] B. A. Adeyemi, \& Y. A. Ajibade, The comparative effects of simulation games and brainstorming instructional strategies on junior secondary school students' achievement in social studies in nigeria. An International Multi-Disciplinary Journal, Ethiopia, vol. 5, no, 3, pp. 64-80. 2011.

[34] M. O. Afuwape, Simulation game-assisted instruction student cognitive style and numerical ability as determinants of learning outcomes in integrated science in Oyo state, Nigeria. Ph.D Thesis, University ofIbadan. 2002.

[35] A, Aremu, \& A. Adebagbo,. "Games, game flow, and gender as they affect mathematics achievement of pupils in nigeria. Bulgarian journal of science and education policy (bjsep), vol. 10, no.1, pp.156173. 2016.

[36] R. A. Ogunkunle, "Effects of gender on the mathematics achievement of students in constructivist and non-constructivist groups in secondary schools. ABACUS". Journal of Mathematical Association of Nigeria, vol. 32, no. 1, pp. 42-50, 2007.

[37] J. Groff. C. Howells, \& S. Cranmer. The impact of games in the classroom: Evidence from schools in Scotland. Bristol, Futurelab. 2010.

[38] N. Vos, H. Van der Meijden, \&E. Denessen, "Effects of constructing versus playing an educational game on student motivation and deep learning strategy use". Computers \& Education, vol. 56 pp. 127-137, 2011.

[39] F. Dotun, "Mathematical game for teaching simple substitution of values into algebraic expressions". Journal of Issues on Mathematics STAN vol. 8, no 2005, pp. 97-105. 2010.

[40]. L. Johnson, R. Smith, H. Willis, A. Levine, and K. Haywood. The 2011 Horizon Report. Austin, Texas: The New Media Consortium. 2011.

[41]. F. M. Reimers, (2008, October 8). "Preparing students for the flat world". Education Week. Available: http://www.edweek.org

[42]. E., Fladen, \& K. Blashki, 2005). Learning playing: Interactive learning and game-based design principles. Paper presented at the 22nd acsilite annual conference, Brisbane, Australia. Available: http://www.ascilite.org.

[43]. A. J. Burguillo, "Using game theory and competition-based learning to stimulate student motivation and performance". Computers and Education, vol. 55, pp. 566-575. 2010.

[44]. M. Papastergiou Digital game-based learning in high school computer science education: impact on educational effectiveness and student motivation. Computers \& Education, vol. 52, pp. 1-12, 2009. 
[45]. S. Kim, \& M. Chang, "Computer games for the math achievement of diverse students". Educ. Technology \& Society, vol. 13, pp.224-232. 2010.

[46] A. Bakar, Y, Inal, \&K. Cagiltay," Interaction patterns of children while playing computer games" pp. 575-580. 2006.

[47] F. Ke, "Computer games application within alternative classroom goal structures: cognitive, metacognitive, and affective evaluation". Education Tech. Res. Dev., vol. 56, pp. 539-556. 2008.

[48] E. Okigbo, \& N. F. Okeke. Game and analogy: A bi-model for effective instruction in the Nigerian mathematics classroom. Universal Journal of Education and General Studies Online Journal of Education Technology, vol. 3 no. 11, 2013 